\title{
Manfaat Bromelin dari Ekstrak Buah Nanas (Ananas comosus L. Merr) dan Waktu Pemasakan untuk Meningkatkan Kualitas Daging Itik Afkir
}

\author{
Dhiah Putri Utami, Pudjomartatmo dan Adi Magna Patriadi Nuhriawangsa \\ Program Studi Peternakan, Fakultas Pertanian Universitas Sebelas Maret \\ Jl. Ir. Sutami 36A Surakarta 57126,E-mail: magnapatriadi@yahoo.com
}

\begin{abstract}
ABSTRAK
Penelitian bertujuan untuk mengetahui pengaruh aras penambahan ekstrak buah nanas (Ananas comosus L. Merr) yang mengandung bromelin, aras waktu pemasakan dan interaksi antara kedua faktor terhadap keempukan, kekuatan tarik, $\mathrm{pH}$, daya ikat air (DIA) dan susut masak daging itik afkir. Itik yang digunakan adalah 18 itik Mojosari umur 84 minggu. Sampel untuk uji keempukan dan kekuatan tarik menggunakan daging paha bawah, uji pH, DIA dan susut masak menggunakan daging paha bagian atas. Rancangan penelitian menggunakan Rancangan Acak Lengkap (RAL) Pola Faktorial $4 \times 3$, dengan faktor pertama penambahan ekstrak buah nanas $(0,5,10,15 \%)$ dan faktor kedua waktu pemasakan $(0,30,60$ menit). Terdapat interaksi antara penambahan ekstrak buah nanas dan waktu pemasakan $(\mathrm{P}<0,01)$ pada $\mathrm{pH}$, DIA, susut masak dan $(\mathrm{P}<0,05)$ pada kekuatan tarik. Penambahan ekstrak buah nanas dan waktu pemasakan dapat meningkatkan keempukan, $\mathrm{pH}$, daya ikat air dan menurunkan susut masak daging itik. Penambahan ekstrak buah nanas $15 \%$ dan waktu pemasakan 60 menit menghasilkan kualitas daging itik yang terbaik.
\end{abstract}

Kata kunci : ekstrak buah nanas, pemasakan, daging, itik afkir, kualitas fisik

\section{The Use of Bromelin from Pineapple (Ananas comosus L. Merr) Extract and Different Cooking Time to Increase Meat Quality of Post Production Ducks}

\begin{abstract}
The research was purposed to know the levels of pineapple extract addition (Ananas comosus L. Merr) with bromelin compound, cooking time and the interaction between two factors on the shear force, the tensile strength, $\mathrm{pH}$, water holding capacity (WHC) and cooking loss (CL) of post production duck meat. The experiment used 18 Mojosari duck with average age 84 weeks. The samples for shear force and tensile strength used drum stick, $p H$, WHC and CL exam used thigh. The data were analyzed by analysis of variance from Completely Randomized Design (CRD) of Factorial Pattern $4 \times 3$, with factor of pineapple extract addition (0, 5, 10, $15 \%)$ and cooking time (0, 30, 60 minutes). There were interactions between pineapple extract addition and cooking time on $\mathrm{pH}$, WHC and CL $(P<0.01)$ and tensile strength $(P<0.05)$. The addition of pineapple extract and cooking time improved tenderness, $p H, W H C$ and decreased $C L$ of duck meat. The addition of pineapple extract at 15\% and cooking time 60 minutes produced the best quality of duck meat.
\end{abstract}

Key words: pineapple extract, cooking time, meat, post production duck, physical quality 


\section{PENDAHULUAN}

Daging itik mempunyai kualitas rendah karena bau amis, bertekstur kasar dan alot (Chang et al., 2005). Daging itik mempunyai kandungan lemak dan protein lebih tinggi, juga mempunyai kandungan kalori lebih rendah dibanding daging unggas yang lain (Srigandono, 1986). Keempukan daging dipengaruhi oleh protein jaringan ikat, semakin tua ternak jumlah jaringan ikat lebih banyak, sehingga meningkatkan kealotan daging. Kekurangan tersebut menyebabkan nilai jual daging itik afkir rendah, karena konsumen menghendaki daging yang mempunyai mutu yang baik, terutama dalam hal keempukan, cita rasa dan warna.

Kualitas daging dipengaruhi oleh metode pemasakan dan metode pemasakan dipengaruhi oleh suhu dan lama waktu pemasakan. Nuhriawangsa (2004) lama pemasakan pada waktu tertentu dapat meningkatkan kualitas daging itik afkir. Lama waktu pemasakan dapat mempengaruhi kualitas daging karena struktur mikro dan kandungan nutrien daging berubah (Soeparno, 2005). Selanjutnya dinyatakan pula dengan terlepasnya asam lemak terbang dan berubahnya struktur mikro dapat meningkatkan flavor dan keempukan daging.

Bromelin termasuk dalam golongan protease yang dihasilkan dari ekstraksi buah nanas yang dapat mendegradasi kolagen daging, sehingga dapat mengempukan daging (Illanes, 2008). Nanas merupakan buah yang dapat diperoleh di seluruh Indonesia dan dapat dipanen sepanjang tahun (Winastia, 2011). Enzim bromelin mudah di dapat karena buah nanas dapat berbuah sepanjang tahun dan tersebar di seluruh Indonesia.

Berdasarkan uraian diatas, maka perlu dilakukan penelitian yang bertujuan untuk mengetahui kualitas daging itik afkir sebagai akibat penambahan ekstrak buah nanas dan waktu pemasakan yang berbeda serta interaksi diantaranya.

\section{MATERI DAN METODE}

Bahan yang digunakan untuk penelitian adalah itik Mojosari afkir umur 84 minggu berjumlah 18 ekor dan buah nanas tua tidak terlalu matang. Preparasi daging itik dengan cara memisahkan daging dari komponen lain pada bagian paha atas (thigh) dan bawah (drum stick) (Soeparno, 2005). Paha bawah digunakan untuk uji keempukan dan kekuatan tarik dan paha atas untuk uji $\mathrm{pH}$, DIA dan susut masak. Preparasi ekstrak buah nanas dengan metode pem-blender-an dan penyaringan (Asryani, 2007).

Kualitas keempukan daging diperoleh dengan cara memasukan enzim dalam daging (Payne, 2009). Enzim dimasukan dalam daging dengan cara dioleskan pada permukaan daging dan ditusuk-tusuk dengan garpu. Aras penambahan ekstrak buah nanas masing-masing 0 (kontrol), 5 (5 ml ekstrak buah nanas dalam 100 gram daging), 10 (10 ml ekstrak buah nanas dalam 100 gram daging) dan 15\% (15 ml ekstrak buah nanas dalam 100 gram daging). Daging setelah diolesi ekstrak buah nanas diinkubasi selama 30 menit pada suhu kamar. Daging dibungkus dengan plastik PP, dikukus pada suhu $60^{\circ} \mathrm{C}$ dengan waktu yang berbeda $(0$, 30, dan 60 menit).

Pengukuran daya putus dan daya tarik daging menggunakan metode Person and Dutson dengan lioyd instrument dalam satuan newton (Murtini dan Qomarudin, 2003), $\mathrm{pH}$ menggunakan $\mathrm{pH}$ meter (Bouton et al., 1971), DIA dengan metode Hamm (Abustam, 2009) dan susut masak menggunakan metode Soeparno (2005).

Rancangan percobaan menggunakan Analysis of Variance (ANOVA) RAL Pola Faktorial. Jika terdapat perbedaan tiap aras perlakuan dilanjutkan dengan uji Duncan's New Multiple Range Test (DMRT) (Hanafiah, 2004).

\section{HASIL DAN PEMBAHASAN}

Rerata daya tusuk, daya putus, $\mathrm{pH}$, DIA dan susut masak daging itik afkir dengan penambahan ekstrak buah nanas 0,5 , 
10 dan 15\% dan dimasak selama 0, 30 dan 60 menit tampak pada Tabel 1.

\section{Daya Putus Daging}

Nilai daya putus daging dengan penambahan ekstrak buah nanas $0 \%$ berbeda dengan 5, 10 dan 15\%. Penambahan 5\% ekstrak buah nanas menurunkan keempukan daging dibanding kontrol dan secara deskritif konsentrasi bertambah dapat meningkatkan keempukan daging. Istika (2009) kolagen dan miofibril terhidrolisis oleh protease, sehingga menyebabkan ikatan struktur daging menjadi fragmen yang lebih pendek dan membuat daging lebih empuk. Kinerja enzim dipengaruhi oleh konsentrasi enzim dan semakin tinggi jumlah enzim akan semakin tinggi substrat yang terhidrolisis (Nelson dan Cox, 2000). Kolagen dan myofibril sebagai substrat akan dihidrolisis oleh protease, sehingga semakin tinggi protease maka kolagen dan miofibril semakin banyak yang terhidrolisis.

Daya putus lama pemasakan 30 menit lebih rendah dibanding kontrol dan lama pemasakan 30 menit tidak berbeda terhadap 60 menit, meskipun secara deskriptif menunjukan penurunan. Daya tusuk semakin turun menunjukan bahwa daging semakin empuk. Menurut Komala (2002) lama pemasakan mempengaruhi pelarutan atau pelunakan kolagen, dengan waktu pemasakan lebih lama kolagen yang larut akan lebih banyak dan akan meningkatkan nilai keempukan daging.

\section{Daya Tarik Daging}

Daya tarik mempunyai nilai menurun dengan bertambahnya konsentrasi ekstrak buah nanas. Nilai kekuatan tarik daging menurun mengindikasikan terjadinya peningkatan keempukan daging. Soeparno (2005) uji kekuatan tarik lebih mengukur keempukan daging yang disebabkan oleh keempukan serat miofibril. Astutiamin's (2009) pertambahan konsentrasi enzim akan menaikan kecepatan reaksi dan hidrolisis substrat. Kenaikan hidrolisis jaringan ikat daging pada miofibril daging menyebabkan daging empuk.

Peningkatan lama waktu pemanasan menurunkan nilai daya tarik daging, sehingga daging semakin empuk. Soeparno (2005) pemasakan daging mengakibatkan perubahan yang spesifik, yaitu pengerutan kolagen menjadi sepertiga dari panjang semula dan akan terjadi pengerutan kolagen menjadi setengah panjang semula yang sering disebut collagen shrinkage (pengerutan kolagen), sehingga struktur daging yang terbentuk oleh kolagen menjadi lunak.

Waktu pemasakan 30 dan 60 menit dengan konsentrasi ekstrak buah nanas 15\% berpengaruh terhadap daya tarik daging, karena terjadi hidrolisis protein pada konsentrasi $15 \%$ yang menurunkan daya tarik daging pada waktu 30 dan 60 menit. Konsentrasi penambahan enzim dan waktu inkubasi berpengaruh terhadap aktivitas enzim (Budiman dan Setyawan, 2009) dan meningkat konsentrasi enzim dapat meningkatkan aktivitas (Renald, 2010).

\section{pH Daging}

Penambahan konsentrasi ekstrak buah nanas dapat menaikan $\mathrm{pH}$ daging. Bromelin memiliki kemampuan untuk memecah molekul protein menjadi bentuk lebih sederhana (Sunarsih, 2008). Bromelin merupakan enzim yang bersifat hidrolase, yaitu enzim yang bekerja dengan adanya air (Budiarti, 2010). Protein mengandung asam amino bersifat hidrofilik, yaitu protein yang residu asam aminonya bersifat menyukai air. Hal ini disebabkan dengan adanya gugus hidrogen pada peptida yang merupakan molekul organik polar, sehingga akan membentuk air dengan adanya gugus $\mathrm{OH}$ (Florence dan Attwood, 2011). Penambahan ekstrak buah nanas mengakibatkan protein jaringan ikat terhidrolisis menjadi beberapa asam amino penyusunnya, sehingga dihasilkan beberapa residu asam amino yang bersifat hidrofilik. Pengikatan air oleh residu asam amino tersebut dapat meningkatkan $\mathrm{pH}$ daging. 
Tabel 1. Rerata nilai daya putus, daya tarik, pH, DIA dan susut masak daging itik afkir dengan aras penambahan ekstrak buah nanas dan aras waktu pemasakan

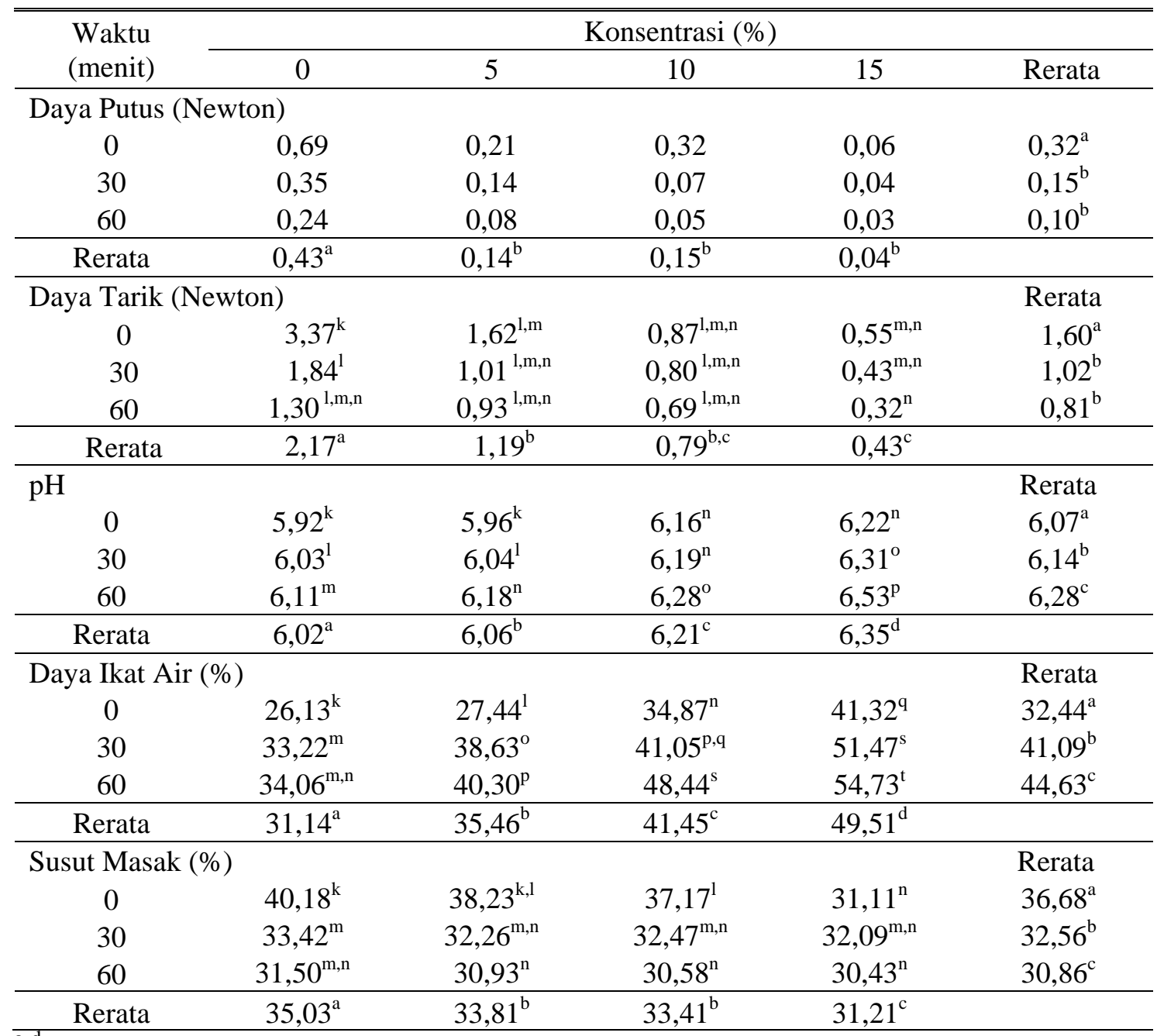

${ }^{\mathrm{a}-\mathrm{d}}$ Superskrip yang berbeda pada kolom atau baris yang sama menunjukkan perbedaan yang sangat nyata $(\mathrm{P}<0,01)$.

${ }^{\mathrm{k}-\mathrm{t}}$ Superskrip yang berbeda pada kolom atau baris yang sama menunjukkan perbedaan yang nyata $(\mathrm{P}<0,05)$.

Bertambahnya waktu pemasakan dapat meningkatkan $\mathrm{pH}$ daging. Lawrie (2005) peningkatan $\mathrm{pH}$ dapat dipengaruhi oleh perubahan-perubahan denaturasi protein dalam sarkoplasma. Sudrajat (2003) pemasakan dapat menyebabkan denaturasi protein, sehingga protein kehilangan gugus asidiknya dan $\mathrm{pH}$ daging meningkat.

Terdapat interaksi antara penambahan ekstrak buah nanas dan waktu pemasakan terhadap $\mathrm{pH}$ daging. Penambahan ekstrak buah nanas dan waktu pemasakan menyebabkan hidrolisis dan denaturasi protein, sehingga pada konsentrasi ekstrak buah nanas semakin meningkat memerlukan waktu pemasakan yang lebih pendek. Hal ini berhubungan dengan jumlah residu asam amino yang terbentuk dan hilangnya gugus asidik protein.

\section{Daya Ikat Air}

Daya ikat air mengalami peningkatan dengan adanya penambahan konsentrasi ekstrak buah nanas. Menurut Abustam's (2009) DIA dipengaruhi oleh $\mathrm{pH}$, pada $\mathrm{pH}$ yang lebih tinggi dari $\mathrm{pH}$ isolektrik protein daging, sejumlah muatan positif dibebaskan 
dan terdapat surplus muatan negatif yang mengakibatkan penolakan dari miofilamen dan memberi lebih banyak ruang untuk molekul air, semakin banyak molekul air dalam daging DIA daging akan naik.

Daya ikat air meningkat dengan bertambahnya waktu pemasakan. Soeparno (2005) pemasakan menyebabkan perubahan DIA karena adanya tingkat kelarutan protein daging. Waktu pemasakan menyebabkan stabilitas protein terganggu dengan adanya denaturasi protein, sehingga semakin banyak protein terdenaturasi maka tingkat kelarutan protein semakin tinggi dan DIA meningkat.

Terdapat interaksi antara penambahan ekstrak buah nanas dan waktu pemasakan terhadap DIA daging. DIA meningkat dengan bertambahnya konsentrasi ekstrak buah nanas dan waktu pemasakan. Soeparno (2005) tingkat kelarutan kolagen meningkat dengan meningkatnya waktu pemasakan. Florence dan Attwood (2011) hidrolisis protein dapat menghasilkan residu asam amino yang bersifat hidrofilik. Kenaikan tingkat kelarutan protein mengakibatkan kenaikan DIA dan hidrolisis protein dapat meningkatkan residu asam amino hidrofilik yang bersifat mengikat air, sehingga kombinasi kedua faktor tersebut dapat meningkatkan tingkat kelarutan protein dan meningkatkan DIA.

\section{Susut Masak}

Penambahan ekstrak buah nanas dapat menurunkan nilai susut masak daging. Bromelin ekstrak buah nanas menghidrolisis jaringan ikat protein daging diantaranya kolagen daging (Illanes, 2008), sehingga dapat membuka struktur mikro daging dengan terputusnya miofibril (Nowak, 2011). Pengujian susut masak menggunakan metode pemasakan yang mengakibatkan terjadinya gap cairan daging dan cairan tersebut dapat tereksudasi keluar mikro struktur daging (Soeparno, 2005), sehingga terjadi penurunan nilai susut masak pada daging.

Susut masak mengalami penurunan dengan bertambahnya waktu pemasakan.
Protein dengan pemanasan terdenaturasi, teragulasi dan mencair membentuk gelatin yang akhirnya termobilisasi bercampur lemak dan air (Judge et al., 1989). Perubahan tersebut dapat menyebabkan cairan daging keluar secara perlahan ketika pemasakan, sehingga daging yang dimasak lebih lama memiliki susut masak lebih kecil.

Terdapat interaksi antara penambahan ekstrak buah nanas dan waktu pemasakan terhadap susut masak daging. Fisher (2009) faktor yang berpengaruh terhadap kecepatan hidrolisis diantaranya konsentrasi enzim dan waktu inkubasi. Arindradita (2009) banyaknya jaringan ikat yang terhidrolisis meningkat dengan bertambahnya konsentrasi enzim dan waktu inkubasi, sehingga semakin tinggi konsentrasi enzim akan memerlukan waktu pemasakan yang lebih pendek.

\section{KESIMPULAN}

Penambahan ekstrak buah nanas dan waktu pemsakan meningkatkan keempukan (daya tarik dan daya putus), pH, DIA dan menurunkan susut masak daging itik afkir.

Penambahan ekstrak buah nanas 15\% dengan waktu pemasakan 60 menit menghasilkan kualitas daging itik afkir yang terbaik.

\section{DAFTAR PUSTAKA}

Abustam, E., 2009. Sifat-Sifat Daging Segar. Web-site: www.sifat-sifat-daging.html. Diakses: Tanggal 08 Maret 2010.

Arindradita, 2009. Enzim. Web-site: http://tekimerzitez.wetpaint.com. Diakses: Tanggal 01 Juni 2010.

Asryani, D. M., 2007. Eksperimen Pembuatan Kecap Manis dari Biji Turi dengan Bahan Ekstrak Buah Nanas. Skripsi. Fakultas Teknik, Universitas Negeri Semarang, Semarang.

Astuiamin's, 2009. Enzim dan Koenzim. Website: http://astutiamin.wordpress.com/. Diakses: Tanggal 01 Juni 2010.

Bouton, P. E., P. V. Harris, and W. R. Shorthose, 1971. Effect of ultimate $\mathrm{pH}$ upon the water- 
holding capacity and tenderness of mutton. J. Food Sci. 36:435-439.

Budiarti, 2010. Percobaan Tentang Enzim. Wabsite: http://littlefairy8.wordpress.com. Diakses: Tanggal 13 Mei 2010.

Budiman, A., dan Setyawan, S., 2009. Pengaruh Konsentrasi Substrat, Lama Inkubasi dan $\mathrm{pH}$ dalam Proses Isolasi Enzim Xylanase dengan Menggunakan Media Jerami Padi. Laporan Penelitian. Universitas Diponegoro, Semarang.

Chang, H. S., N. L. Castro, and M. L. L. Malabayabas, 2005. Duck Marketing in The Philippines: Issues and Opportunities. In: Agricultural and Resource Economic 2005. Page: 1-24.

Florence, A. T., and D. Attwood, 2011. Peptides, Proteins and Other Biopharmaceuticals. In: Physicochemical Principles of Pharmacy. Pharmaceutical Press Pub., London, United Kingdom. Page:451-476.

Fisher, N. 2009. Hidrosilat Protein Ikan. Wabsite:

http://naKEd_fiSHer.archive.com. Diakses: Tanggal 01 Juni 2010.

Hanafiah, K., 2004. Rancangan Percobaan Teori dan Aplikasi. Raja Grafindo Persada, Jakarta.

Illanes, A., 2008. Enzyme Production. In: Enzyme Biocatalysis: Principles and Applications: Enzyme Production. A. Illanes, Ed. Springer Pub., Chile. Page: 57106.

Istika, D., 2009. Pemanfaatan Enzim Bromelain pada Limbah Kulit Nanas (Ananas comosus (L.) Merr) dalam Pengempukan Daging. Laporan Penelitian. Jurusan Biologi. Fakultas Matematika dan Ilmu Lingkungan Pengetahuan Alam, Universitas Sebelas Maret, Surakarta.

Judge, M. D., E. D. Aberle, J. C. Forrest, H. B. Hedrick, and, R. A. Merkel, 1989. Principles of Meat Scince. $2^{\text {nd }}$ ed. Kendal/Hunt Pub. Co., Dubuque, Iowa.

Komala, R. 2002. Pengaruh Umur Potong terhadap Komposisi Kimia dan Sifat Fisik Daging Itik Turi Betina. Skripsi. Fakultas Peternakan, Universitas Gadjah Mada, Yogyakarta.
Lawrie, R. A., 2005. Meat Science. Edisi Ke-5. Penterjemah: A. Perakasi. UI Press, Jakarta.

Murtini, E. S., dan Qamaruddin, 2003. Pengempukan Daging dengan Enzim Protease Tanaman Biduri (Calotropis gigantean). Jurnal Teknologi dan Industri Pangan. 14(3):266-268.

Nuhriawangsa, A. M. P., 2004. Pengaruh Waktu dan Lama Pemanggangan terhadap Kualitas Daging Itik Afkir. Jurnal Pengembangan Peternakan Tropis. Edisi Khusus Nopember. Hal: 122-127.

Nelson, D. L., and M. M. Cox, 2000. Lehninger Principles of Biochemistry. $3^{\text {rd }}$ ed. Worth Pub., New York.

Nowak, D., 2011. Enzymes in Tenderization of Meat: The System of Calpains and Other Systems: A Review. Pol. J. Food Nutr. Sci. 61(4): 231-237.

Payne, C. T., 2009. Enzymes. In: Ingredients in Meat Product. Rodrigo Tarte, Ed. Springer Pub., New York.

Renald, 2010. Kecepatan Reaksi Hidrolisis Amilum oleh Enzim Amilase. Web-site: http://www.scribd.com. Diakses: Tanggal 01 Juni 2010.

Sunarsih, L., 2008. Uji Efektivitas Ekstrak Buah Nanas (Ananas comosus L. Merr) Muda Varietas Queen Terhadap Mortalitas

Cacing Parasit (Ascaridia Galli) Secara In Vitro. Skripsi. Fakultas Keguruan dan Ilmu Pendidikan, Universitas Muhamadiyah Malang, Malang.

Srigandono, B., 1986. Ilmu Unggas Air. Gadjah Mada University-Press, Yogyakarta.

Soeparno, 2005. Ilmu dan Teknologi Daging. Gadjah Mada University-Press, Yogyakarta.

Sudrajat, A., 2003. Pengaruh Temperatur dan Lama Pemasakan terhadap Karakteristik Fisik dan Organoleptik Daging Ayam Broiler. Skripsi. Fakultas Peternakan, Universitas Gadjah Mada, Yogyakarta.

Winastia, B., 2011. Analisa Asam Amino pada Enzim Bromelin dalam Buah Nanas. (Ananas Comusus) Menggunkan Spektrofotometer. Tugas Akhir. Program Studi Diploma III Teknik Kimia, Program Diploma, Fakultas Teknik Universitas Diponegoro, Semarang. 